\title{
Hubungan antara Lingkungan Keluarga dan Hasil Belajar IPS Siswa Kelas V SDN Sekecamatan Ambal Tahun Ajaran 2019/2020
}

\author{
Umi Hanifah', Drs. Joharman, M.Pd. ${ }^{2}$, Dr. Suhartono, M.Pd. ${ }^{3}$ \\ 1,2,3 Universitas Sebelas Maret \\ umihanifah@student.uns.ac.id
}

\section{Article History}

accepted 01/02/2020

approved 01/03/2020

published 01/04/2020

\begin{abstract}
Social science learning outcomeis one of indicatorssucceedin education. Each student has different social science learning outcome. Family environmenteffects the outcome. The study aims to determine: (1) the positive and significant correlation between family environment and social science learning outcome, (2) the contribution of family environment towardsocial science learning outcome. The study is a quantitative research methods with bivariate correlation. Data collection techniques are test and questionnaire. The sampling technique used in the study isprobability sampling. Data are analyzed by using correlation test with significance level of 0.05 and determinant coefficient formula to determine the variable contribution. The resultis $p$ value $0.001<0.05$ withcoefficient correlation of 0.204 , while the determinant coefficient is $4.16 \%$. It concludes that: (1) there is positive and significant correlation between family environment and social science learning outcome, (2) the contribution of family environment tosocial science learning outcomeis $4.16 \%$ and $95.84 \%$ is caused by other factors.
\end{abstract}

Keywords: learning, family, environment

\begin{abstract}
Abstrak
Hasil belajar IPS merupakan salah satu indikator keberhasilan dalam pendidikan. Hasil belajar IPS setiap siswa pada umumnya berbeda. Hal tersebut karena terdapat beberapa faktor yang mempengaruhi, salah satunya adalah lingkungan keluarga. Pada penelitian ini bertujuan untuk mengetahui: (1) adanya hubungan positif dan signifikan antara lingkungan keluarga dan hasil belajar IPS, (2) besar sumbangan lingkungan keluarga terhadap hasil belajar IPS. Penelitian merupakan penelitian kuantitatif dengan metode korelasi bivariat. Pengambilan data dilakukan dengan instrumen tes dan angket. Teknik pengambilan sampel yang digunakan dalam penelitian adalah probability sampling. Analisis data menggunakan uji korelasi dengan taraf signifikansi 0,05 dan mencari sumbangan variabel dengan rumus koefisien determinan. Hasil penelitian menunjukan bahwa nilai $p$ value $0,001<0,05$ dengan koefisien korelasi sebesar 0,204 . Sedangkan koefisien determinannya sebesar $4,16 \%$. Berdasarkan uraian tersebut, bisa disimpulkan bahwa: (1) terdapat hubungan positif dan signifikan antara lingkungan keluarga dan hasil belajar IPS, (2) sumbangan lingkungan keluarga terhadap hasilbelajar IPS yaitu $4,16 \%$ dan selebihnya $95,84 \%$ diberikan oleh faktor lain.
\end{abstract}

Kata kunci: belajar, keluarga, lingkungan 


\section{PENDAHULUAN}

Pendidikan memegang peranan penting dalam pengembangan diri anak menjadi pribadi yang berkualitas. Ragam pengembangan diri anak yang dapat dilakukan seperti pembentukan kebiasaan, minat, sikap, kesusilaan, serta keagamaan. Hal ini sesuai dengan tujuan pendidikan nasional dalam UU RI Nomor 20 tahun 2003 tentang Sisdiknas Bab I Pasal 1 yang menyebutkan bahwa melalui pendidikan, Indonesia mampu menciptakkan generasi bangsa yang beriman takwa, berkarakter, berakhlak mulia, berpengetahuan, kreatif, dan terampil.

Keberhasilan pendidikan dapat dilihat dari nilai hasil belajar yang diperoleh siswa. Semakin tinggi nilai hasil belajar yang dimiliki oleh siswa maka akan semakin baik pula keberhasilan pendidikan yang dilakukan. Menurut Susanto (2016:5) hasil belajar adalah segala perubahan yang terjadi pada diri siswa, baik yang menyangkut aspek kognitif, afektif, dan psikomotor sebagai hasil dari kegiatan belajar yang telah dilakukan. Sementara, menurut Samlawi dan Maftuh (2001) IPS merupakan mata pelajaran yang memadukan ilmu sosial yang diajarkan kepada siswa dengan memperhatikan kesesuaian dan kebermaknaan materi. Dengan demikian dapat disimpulkan bahwa hasil belajar IPS merupakan perubahan kognitif pada diri siswa yang diperoleh setelah mengikuti mata pelajaran terpadu tentang ilmu sosial yang telah disesuaikan dengan tahap perkembangan anak.

Pada umumnya setiap siswa memiliki hasil belajar IPS yang berbeda. Seperti halnya dengan nilai hasil belajar IPS siswa kelas V di SD Negeri Pucangan, sebagian besar siswa memiliki hasil belajar yang berbeda. Hal itu bisa terjadi karena hasil belajar dipengaruhi oleh beberapa faktor yang berasal dari dalam diri siswa ataupun dari luar diri siswa. Salah satu faktor dari luar diri siswa yang mempengaruhi hasil belajar adalah lingkungan keluarga. Hal tersebut sejalan dengan pendapat Sobur (2016) yang menerangkan bahwa faktor dari luar diri siswa yang mempengaruhi hasil belajar bisa berupa lingkungan keluarga, lingkungan sekolah, dan lingkungan lain tempat individu berada.

Lingkungan merupakan segala sesuatu yang mampu mempengaruhi tingkah laku, pertumbuhan, dan perkembangan seseorang, kecuali gen (Purwanto, 2007). Sementara, keluarga merupakan semua pihak yang memiliki hubungan darah atau keturunan antara satu dengan lainnya (Sadulloh, Robandi, dan Muharam, 2006). Sehingga dapat disimpulkan bahwa lingkungan keluarga merupakan semua pihak yang memiliki hubungan darah atau keturunan yang mampu mempengaruhi tingkah laku, pertumbuhan, dan perkembangan seseorang.

Lingkungan keluarga menjadi lingkungan terpenting dalam perkembangan pendidikan seorang siswa. Hal ini karena keluarga merupakan tempat pertama kali seorang siswa untuk berkomunikasi dan melakukan sosialisasi. Proses sosialisasi tersebut berupa komunikasi orang tua pada anak yang pada akhirnya mampu menciptakan hubungan kuat di antara keduanya dan suasana rumah yang nyaman. Dengan adanya kenyamanan dan hubungan yang harmonis antaranggota keluarga menjadikan lingkungan keluarga berpengaruh terhadap hasil beajar siswa. Hal tersebut sesuai dengan pendapat Slameto (2010:60) yang mengungkapkan bahwa lingkungan keluarga mampu mempengaruhi hasil belajar. Sejalan dengan pendapat tersebut, Rolande (Kaukab, 2016) menerangkan bahwa keterlibatan orang tua dalam segala hal tentang sekolah anak mampu mempengaruhi hasil belajar anak.

Pada penelitian ini menggunakan pendapat Slameto sebagai indikator lingkungan keuarga. Menurut Slameto (2010) beberapa indikator lingkungan keluarga yang mampu mempengaruhi hasil belajar anak meliputi: (1) cara orang tua mendidik, (2) hubungan antaranggota keluarga, (3) suasana rumah, (4) keadaan ekonomi keluarga, (5) perhatian orang tua, dan (6) latar belakang kebudayaan keluarga. Pada penelitian ini menggunakan pendapat Slameto sebagai indikator lingkungan keluarga. 
Berdasarkan uraian di atas, penelitian ini dilakukan dengan tujuan: (1) mengetahui adanya hubungan positif dan signifikan antara lingkungan keluarga dengan hasil belajar IPS siswa kelas V SDN se-Kecamatan Ambal, dan (2) mengetahui besarnya sumbangan variabel lingkungan keluarga terhadap hasil belajar IPS siswa kelas V SDN se-Kecamatan Ambal.

\section{METODE}

Penelitian ini adalah penelitian kuantitatif dengan metode korelasi bivariat. Metode penelitian ini merupakan penelitian yang bertujuan untuk mengetahui hubungan antar satu buah variabel dependen dengan satu buah variabel independen. Populasi dalam penelitian adalah seluruh siswa kelas V SDN se-Kecamatan Ambal tahun ajaran 2019/2020. Sampel penelitian dihitung dengan menggunakan rumus probability sampling. Hasil perhitungan tersebut menghasilkan sebanyak 250 siswa kelas $\mathrm{V}$ dari 10 sekolah dasar negeri di Kecamatan Ambal sebagai sampel penelitian.

Teknik pengumpulan data dilakukan dengan menggunakan instrumen angket dan tes. Angket digunakan untuk mengumpulkan data lingkungan keluarga siswa dan tes digunakan untuk mengumpulkan data hasil belajar IPS siswa kelas V. Instrumen terlebih dahulu diuji validitas dan reliabilitasnya sebelum akhirnya digunakan dalam penelitian. Pengumpulan data untuk Uji instrumen dilakukan pada 79 siswa kelas $\mathrm{V}$ di dua sekolah yang bukan merupakan sampel.

Teknik analisis data dilakukan dengan uji prasyarat dan uji hipotesis. Pada uji prasyarat penelitian ini dilakukan uji normalitas dan linieritas. Sementara, uji hipotesis dilakukan dengan uji korelasi dan perhitungan koefisien determinan.

\section{HASIL DAN PEMBAHASAN}

Hasil belajar IPS siswa kelas V dalam penelitian ini adalah sebagai variabel dependen atau terikat. Instrumen yang digunakan untuk mengambil data hasil belajar IPS siswa kelas $V$ yaitu instrumen tes. Sebelum digunakan dalam penelitian butir soal telah diujicobakan kepada 79 siswa untuk kemudian dianalisis kevalidan butir soal. Pada penelitian ini terdapat 34 butir soal yang valid. Butir soal yang tersebut yang akan digunakan dalam penelitian untuk diujikan pada siswa yang menjadi sampel penelitian. Data yang diperoleh kemudian dimasukan dalam MS. Exel dan dianalisis menggunakan aplikasi SPSS.

Hasil perhitungan analisis deskriptif variabel hasil belajar IPS siswa kelas V dapat dilihat pada tabel 1.1.

Tabel 1.1 Hasil Analisis Deskriptif Hasil Belajar IPS Siswa Kelas V

\section{Statistics}

HASIL BELAJAR

\begin{tabular}{lr}
\hline N & Valid \\
\cline { 2 - 2 } \multicolumn{1}{c}{ Missing } & \multicolumn{1}{c}{0} \\
\hline Mean & 20,58 \\
Median & 21,00 \\
Mode & 19 \\
Std. Deviation & 4,257 \\
Variance & 18,123 \\
Skewness &,- 009 \\
Std. Error of Skewness & 154 \\
Kurtosis &,- 212 \\
Std. Error of Kurtosis &, 307 \\
Range & 23 \\
Minimum & 9 \\
Maximum & 32 \\
Sum & 5146 \\
\hline
\end{tabular}


Dari tabel di atas dapat diketahui bahwa rata-rata skor hasil belajar IPS siswa yaitu 20,58. Nilai tengah data hasil belajar IPS adalah 21. Nilai yang sering muncul dalam data hasil belajar IPS siswa adalah 19. Kecenderungan nilai yang hampir sama antara nilai rata-rata, nilai tengah, dan nilai yang sering muncul menandakan bahwa data hasil belajar IPS siswa kelas $\mathrm{V}$ memiliki kurva yang simetris dan berdistribusi normal. Hal tersebut sejalan dengan pendapat Abdurahman, Muhidin, dan Somantri (2011: 120) yang berpendapat bahwa apabila suatu data memiliki rata-rata nilai rata, nilai tengah, dan nilai yang sering muncul yang sama maka data tersebut berdistribusi normal.

Pada penelitian ini, lingkungan keluarga merupakan variabel independen atau variabel bebas. Instrumen yang digunakan untuk mendapatkan data lingkungan keluarga siswa yaitu instrumen angket. Sebelum digunakan dalam penelitian, angket terlebih dahulu diuji kevadiannya dengan cara dikonsultasikan kepada dosen pembimbing dan diujikan pada 79 siswa yang bukan sampel penelitian. dan dianalisis dengan SPSS. Jumlah pernyataan angket yang valid dan akan digunakan dalam penelitian ini yaitu 23 butir pernyataan. Setelah angket diujikan pada 250 siswa yang menjadi sampel penelitian, data angket yang berupa ordinal dikonversikan menjadi interval dengan MSI. Selanjutnya data akan dianalisis dengan menggunakan SPSS.

Hasil perhitungan analisis deskriptif variabel lingkungan kelarga dapat dilihat pada tabel 1. 2 .

Tabel 4.2 Hasil Analisis Deskriptif Lingkungan Keluarga

\begin{tabular}{lr}
\hline \multicolumn{2}{c}{ Statistics } \\
\hline $\mathrm{N} \quad$ LINGKUNGAN KELUARGA \\
\cline { 2 - 3 } \multicolumn{1}{c}{ Valid } & 250 \\
\hline Mean & 0 \\
Median & 63,1353 \\
Mode & 63,1390 \\
Std. Deviation & 70,71 \\
Variance & 6,97867 \\
Skewness & 48,702 \\
Std. Error of Skewness &, 112 \\
Kurtosis &, 154 \\
Std. Error of Kurtosis &, 155 \\
Range &, 307 \\
Minimum & 39,44 \\
Maximum & 45,33 \\
Sum & 84,78 \\
\hline
\end{tabular}

Berdasarkan hasil analisis di atas, dapat dilihat bahwa rata-rata data skor angket lingkungan keluarga siswa siswa yaitu 63,1353. Nilai tengah data lingkungan keluarga adalah 63,1390 . Nilai yang sering muncul dalam data lingkungan keluarga siswa adalah 70,71. Kecenderungan nilai yang hampir sama antara nilai rata-rata, nilai tengah, dan nilai yang sering muncul menandakan bahwa data lingkungan keluarga memiliki kurva yang simetris dan berdistribusi normal.

Uji normalitas data pada penelitian ini menggunakan uji lilifors. Data dikatakan normal apabila nilai signifikansi $>0,05$. Nilai signifikansi variabel hasil belajar IPS dan variabel lingkungan keluarga yaitu 0,089 dan 0,200. Berdasarkan hasil analisis kedua variabel tersebut nilai signifikansi $>0,05$, sehingga data variabel hasil belajar IPS dan lingkungan keluarga berdistribusi normal.

Uji linieritas merupakan uji asumsi apakah terdapat hubungan antar variabel dalam bentuk garis lurus atau tidak. Data dikatakan linier $p$ value deviation from linierity 
$>0,05$. Berdasarkan uji linieritas yang telah dilakukan, dapat diketahui bahwa $p$ value deviation from linierity yaitu 0,264 . Hal tersebut berarti $p$ value deviation from linierity $>$ 0,05 , sehingga dapat disimpulkan bahwa terdapat hubungan yang linier antara variabel hasil belajar IPS dan variabel lingkungan keluarga.

Uji korelasi merupakan uji statistik yang bertujuan untuk mengetahui adanya hubungan antar variabel. Variabel lingkungan keluarga dan hasil belajar IPS dikatakan berhubungan apabila $p$ value $<0,05$. Berdasarkan uji korelasi antara lingkungan keluarga dan hasil belajar IPS siswa kelas $\mathrm{V}$ yang telah dilakukan, dapat diketahui nilai $p$ value yaitu 0,001 . Hasil tersebut berarti $p$ value $<0,05$, sehingga dapat disimpulkan bahwa terdapat hubungan antara lingkungan keluarga dan hasil belajar IPS siswa kelas V. Nilai person correlation 0,204 mengartikan bahwa hubungan yang terjadi adalah hubungan positif.

Hasil penelitian tersebut sesuai dengan penelitian yang dilakukan Safitri, Herpratiwi, dan Sugiyanto (2017: 7) yang menyatakan terdapat hubungan yang signifikan dan positif antara lingkungan keluarga dan hasil belajar IPS siswa. Oleh karena itu, dapat dikatakan bahwa semakin tinggi kualitas lingkungan keluarga yang dimiliki siswa maka semakin tinggi pula hasil belajar IPS yang dimiliki siswa, dan sebaliknya semakin rendah kualitas lingkungan keluarga yang dimiliki siswa maka akan semakin rendah hasil belajar IPS yang dimiliki.

Selain penelitian di atas, penelitian lain yang relevan dengan hasil penelitian ini yaitu penelitian yang dilakukan oleh Tresnati (2016:127) menyatakan bahwa lingkungan keluarga memiliki hubungan dengan hasil belajar IPS yang dimiliki siswa SD dengan koefisien korelasi 0,666. Kesesuaian hasil penelitian dengan penelitian sebelumnya membuktikan bahwa lingkungan keluarga memiliki hubungan positif dan signifikan dengan hasil belajar IPS siswa kelas V SDN se-Kecamatan Ambal tahun ajaran 2019/2020.

Koefisien determinan pada penelitian ini digunakan untuk menghitung seberapa besar sumbangan lingkungan keluarga terhadap hasil belajar IPS siswa. Sebelum dilakukan perhitungan koefisien determinan, dicari terlebih dahulu koefisien korelasinya. Koefisien korelasi yang didapatkan yaitu 0,204. Hasil perhitungan koefisien determinan variabel lingkungan keluarga pada hasil belajar IPS didapatkan hasil sebesar $4,16 \%$, artinya lingkungan keluarga dapat berperan meningkatkan hasil belajar IPS sebesar 4,16\% dan sisanya 95,84\% dipengaruhi oleh faktor lain.

\section{SIMPULAN}

Berdasarkan hasil penelitian dan pembahasan hubungan lingkungan keluarga dan hasil belajar IPS siswa kelas V SDN se-Kecamatan Ambal tahun ajaran 2019/2020 dapat ditarik kesimpulan sebagai berikut:

1. Lingkungan keluarga memiliki hubungan positif dan signifikan dengan hasil belajar IPS siswa kelas V SDN se-Kecamatan Ambal tahun ajaran 2019/2020 dengan nilai pearson correlation 0,204.

2. Sumbangan variabel lingkungan keluarga terhadap hasil belajar IPS siswa kelas $V$ SDN se-Kecamatan Ambal tahun ajaran 2019/2020 yaitu 4,16\%.

Berdasarkan simpulan yang telah disebutkan, dapat diberikan beberapa saran sebagai berikut:

1. Bagi Guru

Guru sebaiknya memasukan beberapa indikator lingkungan keluarga pada saat memberikan pengajaran siswa. Indikator yang bisa dilakukan seorang guru yaitu cara mendidik, memberikan perhatian, dan suasana ruangan sehingga semua siswa mampu mendapatkan hasil belajar IPS yang tinggi. 


\section{Bagi Sekolah}

Sekolah hendaknya mampu memberikan pengertian kepada orang tua siswa mengenai pentingnya peran lingkungan keluarga pada hasil belajar IPS siswa sehingga siswa mampu mendapatkan hasil belajar IPS yang tinggi.

3. Bagi Peneliti Selanjutnya

Bagi peneliti yang ingin melakukan penelitian yang hampir sama tentang hubungan lingkungan keluarga dengan hasil belajar IPS siswa dapat menjadi acuan dalam penelitian korelasi dan mencari sumber referensi lainnya sehingga mampu melakukan penelitian yang lebih baik.

\section{DAFTAR PUSTAKA}

Abdurahman, M., Muhidin, S.A., dan Somantri, A. (2011). Dasar-dasar Metode Statistika untuk Penelitian. Bandung: CV Pustaka Setia.

Kaukab, S. R. (2016). The Impact of Parent/Family Involvement on Student' Learning Outcomes. International Journal of Research Granthalayah, 4 (10), 72-81.

Purwanto. (2008). Metodologi Penelitian Kuantitatif untuk Psikologi dan Pendidikan. Yogyakarta: Pustaka Pelajar.

Safitri, R., Herpratiwi., dan Sugiyanto. (2017). Hubungan Lingkungan Keluarga dengan Hasil Belajar IPS Siswa Kelas V. Jurnal Pedagogi FKIP UNILA, 5 (3), 1-9.

Sadulloh, U., Robandi, B., dan Muharam, A. (2006). Pedagogik. Bandung: UPI PressSamlawi, F dan Maftuh, B. (2001). Konsep Dasar IPS. Bandung: CV Maulana.

Samlawi, F dan Maftuh, B. (2001). Konsep Dasar IPS. Bandung: CV Maulana.

Slameto (2010). Belajar dan Faktor-faktor yang Mempengaruhi. Jakarta: Rineka Cipta.

Sobur A. (2016). Psikologi Umum. Bandung: Pustaka Setia.

Susanto, A. (2016). Teori Belajar dan Pembelajaran di Sekolah Dasar. Jakarta: Prenadamedia Group.

Tresnati, K.N. (2016). Skripsi Hubungan Lingkungan Keluarga dan Minat Belajar terhadap Hasil Belajar IPS Siswa Kelas IV SD di Gugus Kresna dan Shinta Kecamatan Semarang Barat. Skripsi Tidak Dipublikasikan, Universitas Negeri Semarang, Semarang. 